\title{
Changes in Eurasian glaciation during the past century: glacier mass balance and ice-core evidence
}

\author{
Vladimir N. Mikhalenko \\ Institute of Geography, Russian Academy of Sciences, 29 Staromonetny st., 109017 Moscow, Russia
}

\begin{abstract}
Glaciers of both the Arctic and mid-latitude mountain systems within Eurasia have retreated intensively during the past century. Measured and reconstructed glacier mass balances show that glacier retreat began around the $1880 \mathrm{~s}$. The mean annual mass-balance value for $1880-1990$ was $-480 \mathrm{~mm} \mathrm{a}^{-1}$ for glaciers with maritime climatic conditions, and $-140 \mathrm{~mm} \mathrm{a}^{-1}$ for continental glaciers. It can be concluded that warming in the Caucasus occurred during at least the last 60 years, according to the distribution of crystal sizes in an ice core from the Dzhantugan firn plateau. Temperatures measured in 1962 at $20 \mathrm{~m}$ on the Gregoriev ice cap, Tien Shan, were $-4.2^{\circ} \mathrm{C}$ while in 1990 they were $-2^{\circ} \mathrm{C}$, a warming of $2.2^{\circ} \mathrm{C}$ over 28 years. Changes in the isotopic composition of glacier ice during the 20 th century indicate recent and continuing warming in different regions of Eurasia. The $\delta^{18} \mathrm{O}$ records reveal an enrichment at the Gregoriev ice cap during the last 50 years, while surface temperatures at the Tien Shan meteorological station have increased $0.5^{\circ} \mathrm{C}$ since 1930 .
\end{abstract}

\section{INTRODUCTION}

Contemporary glaciers in the Arctic islands and low- and mid-latitude mountain systems of Eurasia cover more than $200000 \mathrm{~km}^{2}$. Evidence from moraine studies and glacier mass-balance measurements (Dyurgerov, 1995) shows that, within Eurasia, glaciers have been retreating during the last 100 years since the end of the Little Ice Age. This has resulted in a glacierized area reduced by $10-30 \%$, depending on the mountain region. The rate decreases from west to east, with relaxation of the influence of western atmospheric circulation (Krenke, 1982). The altitude, orientation and geography of the ranges influences how different mountain systems react to climate change. Glaciers with different sizes, shape, orientation and altitude have different response rates. The rate of reduction in glacier water resources has increased measurably because of natural and man-made climate changes during the past century (Dowdeswell,

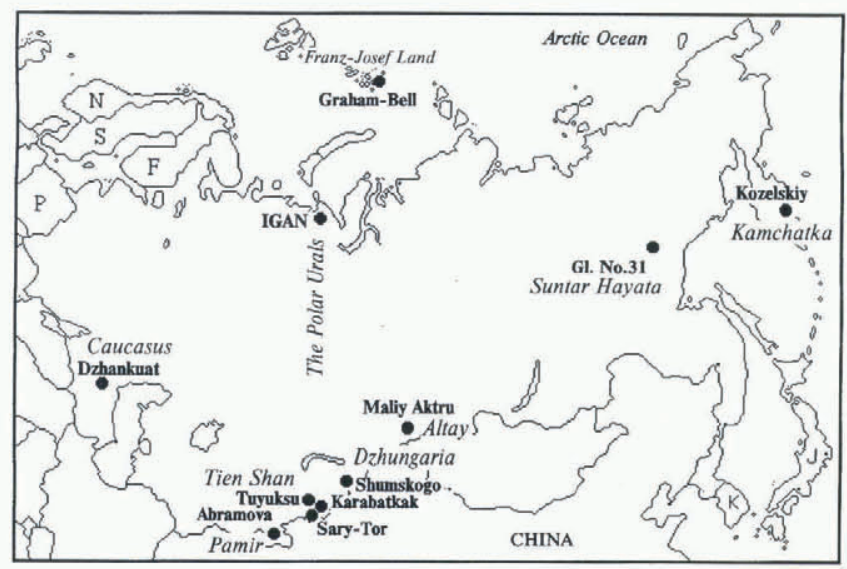

Fig. 1. Location of investigated glaciers.
1995); up to $1 \%$ per year in the mountains of Central Asia (Dyurgerov, 1996). Glacier mass-balance and ice-core investigations allow us to identify the climate that has influenced glaciers during the last 100 years.

\section{DATA BASE}

A long-term series of observed, and reconstructed, glacier mass balance and observations of glacier retreat, from the mid-19th century to the present, are used to investigate glacier behavior over the past century (see Fig. 1; Table 1). The method of glacier mass-balance reconstruction is provided by Mikhalenko and Solomina (1996). The results of deep ice-core drilling at the Eurasian glaciers were also used in the analysis (Table 2). Isotopic composition, ice-crystal distribution and borehole temperatures were studied first. Isotopic composition reflects condensation temperatures during the formation of solid precipitation. Changes in crystal size indicate fluctuations of climate conditions during ice formation. Repeated measurements of ice temperature in boreholes provide information about changes in the thermal regime of the glaciers.

\section{RESULTS}

\section{Glacier mass-balance evidence}

The measured and reconstructed mass-balance series show there were no major changes in glacier volume and extent during the 19th century (Fig. 2). Until 1880, the cumulative mass-balance curves are parallel and close to zero. Glacier mass balance was influenced by negligible oscillations without any considerable trend. Glacier front positions in most mountain systems were stable.

Since 1880, there are two types of mass-balance curve (Fig. 2). The first reflects changes for the glaciers in regions 
Table 1. Glacier reconstructions

\begin{tabular}{|c|c|c|c|c|c|c|c|}
\hline \multirow[t]{2}{*}{ Mountain system } & \multirow[t]{2}{*}{ Glacier } & \multicolumn{2}{|c|}{ Coordinates } & \multirow{2}{*}{$\begin{array}{l}\text { Observation } \\
\text { period }\end{array}$} & \multirow{2}{*}{$\begin{array}{c}\text { Basic } \\
\text { meteorological station }\end{array}$} & \multirow{2}{*}{$\begin{array}{l}\text { Period of } \\
\text { reconstructions }\end{array}$} & \multirow[t]{2}{*}{ Source } \\
\hline & & Lat. $\mathrm{N}$ & Long. E & & & & \\
\hline Caucasus & Dzhankuat & $43^{\circ} 12^{\prime}$ & $42^{\circ} 46^{\prime}$ & 1967-present & $\begin{array}{l}\text { Pyatigorsk } \\
\text { Terskol }\end{array}$ & $1871-1977$ & Dyurgerov and Popovnin (1988) \\
\hline Polar Urals & IGAN & & & $1957-81$ & $\begin{array}{l}\text { Syktyvkar } \\
\text { Khadata }\end{array}$ & $1817-1959$ & $\begin{array}{l}\text { Troitskiy and others (1963) } \\
\text { Voloshina (1988) }\end{array}$ \\
\hline Pamirs & Abramov & $39^{\circ} 40^{\prime}$ & $71^{\circ} 30^{\prime}$ & 1967 present & Fergana & 1882-1992 & Glazyrin and others (1993) \\
\hline \multirow[t]{2}{*}{ Tien Shan } & Tuyuksu & $43^{\circ} 00^{\prime}$ & $77^{\circ} 06^{\prime}$ & 1956-present & $\begin{array}{l}\text { Mynzhilky } \\
\text { Alma-Ata }\end{array}$ & $\begin{array}{l}1937-56 \\
1879-1964\end{array}$ & $\begin{array}{l}\text { Dyurgerov (1995) } \\
\text { Makarevich and others (1969) }\end{array}$ \\
\hline & $\begin{array}{l}\text { Golubina } \\
\text { Sary-Tor } \\
\text { Karabatkak }\end{array}$ & $\begin{array}{l}42^{\circ} 27^{\prime} \\
41^{\circ} 50^{\prime} \\
42^{\circ} 08^{\prime}\end{array}$ & $\begin{array}{l}74^{\circ} 30^{\prime} \\
78^{\circ} 11^{\prime} \\
78^{\circ} 16^{\prime}\end{array}$ & $\begin{array}{l}1958 \text {-present } \\
1985 \text { - } 89 \\
1957 \text {-present }\end{array}$ & $\begin{array}{l}\text { Baytik } \\
\text { Tien Shan } \\
\text { Chon-Kyzilsu }\end{array}$ & $\begin{array}{c}1914-82 \\
1930-88 \\
-\end{array}$ & $\begin{array}{l}\text { Aizen (1988) } \\
\text { Ushnurtsev (1991) } \\
\text { Dikikh and others (1995) }\end{array}$ \\
\hline Dzungaria & Shumskogo & $45^{\circ} 05^{\prime}$ & $80^{\circ} 14^{\prime}$ & 1967-92 & Sarkand & $1930-84$ & Cherkasov (1991) \\
\hline Altai & Maliy Aktru & $50^{\circ} 05^{\prime}$ & $87^{\circ} 45^{\prime}$ & 1971-present & Barnaul & $1838-1985$ & Narozhnyy (1986) \\
\hline Suntar-Hayata & Glacier No. 31 & $62^{\circ} 30^{\prime}$ & $142^{\circ} 30^{\prime}$ & $1957-59$ & Tomtor & 194360 & Koreisha (1963) \\
\hline Kamchatka & Kozelskiy & $53^{\circ} 14^{\prime}$ & $158^{\circ} 49^{\prime}$ & 1973-present & $\begin{array}{l}\text { Petropavlovsk- } \\
\text { Kamchatskiy }\end{array}$ & $1891^{-}$ & $\begin{array}{l}\text { Vinogradov and Murav'yev } \\
\text { (1992) }\end{array}$ \\
\hline
\end{tabular}

Table 2. Ice-core drilling sites

\begin{tabular}{|c|c|c|c|c|c|c|}
\hline \multirow[t]{2}{*}{ Mountain system } & \multirow[t]{2}{*}{ Glacier } & \multicolumn{2}{|c|}{ Coordinates } & \multirow{2}{*}{$\begin{array}{c}\text { Altitude of } \\
\text { drilling site } \\
\mathrm{m}\end{array}$} & \multirow[t]{2}{*}{ Year } & \multirow[t]{2}{*}{ Source } \\
\hline & & Lat. N & Long. E & & & \\
\hline FranzJosef Land & $\begin{array}{l}\text { Windy Ice Cap } \\
\text { Graham Bell Island }\end{array}$ & $80^{\circ} 47^{\prime}$ & $63^{\circ} 32^{\prime}$ & 509 & 1994 & Mikhalenko and others (1996) \\
\hline Kunlun Shan & Guliya ice cap & $35^{\circ} 17^{\prime}$ & $81^{\circ} 29^{\prime}$ & 6200 & 1992 & Thompson and others (1995) \\
\hline Tien Shan & Gregoriev ice cap & $41^{\circ} 58^{\prime}$ & $77^{\circ} 55^{\prime}$ & 4609 & 1990 & Thompson and others (1993) \\
\hline Qilian Shan & Dunde ice cap & $38^{\circ} 06^{\prime}$ & $96^{\circ} 24^{\prime}$ & 5325 & 1986 & Thompson and others (1993) \\
\hline Alps & Colle Gnifetti & & & 4450 & 1982 & Wagenbach (1994) \\
\hline Caucasus & Dzhantugan firn plateau & $43^{\circ} 12^{\prime}$ & $42^{\circ} 46^{\prime}$ & 3850 & 1980 & Golubev and others (1988) \\
\hline
\end{tabular}

with a high intensity of mass exchange (modulus sum of accumulation and ablation) such as the Dzhankuat, Abramova and Kozelskiy glaciers. For such glaciers the average mass balance for the last 110 years is $-480 \mathrm{~mm} \mathrm{a}^{-1}$. Another group of glaciers, within the Tien Shan, the Altai, the Polar Urals, the mountains of northwestern Siberia and Dzungaria, is

$\sum \mathrm{bn}, \mathrm{g} / \mathrm{cm} 2$

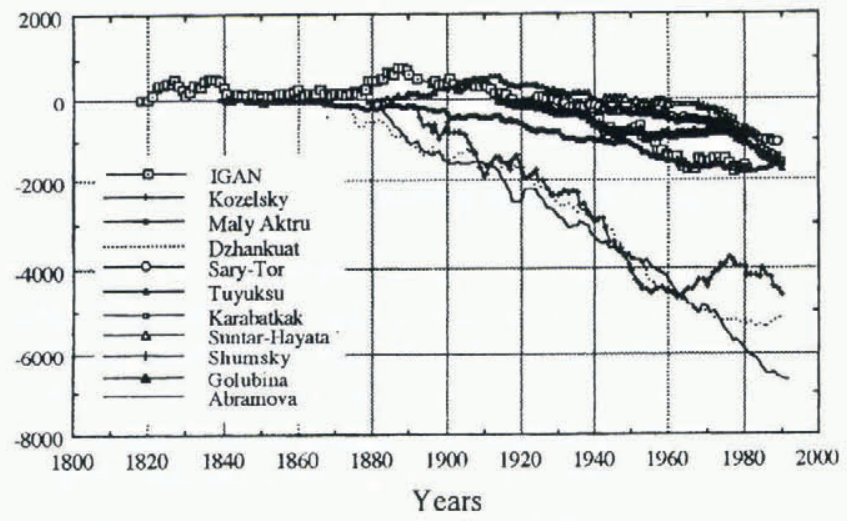

Fig. 2. Cumulative curves of glacier mass balance. characterized by less negative mass-balance values $\left(-140 \mathrm{~mm} \mathrm{a}^{-1}\right)$ for the same period (Fig. 2). Glacier fronts retreated several kilometers in the first group, but only hundreds of meters in the second. Changes in the altitudes of glacier tongues in the maritime regions (Caucasus and Kamchatka) were much more considerable compared with those in more continental areas.

Because of these mass-balance changes, Caucasus glaciers retreated from $700-750 \mathrm{~m}$ up to $3 \mathrm{~km}$ during the last 100 years. Glacier fronts receded to elevations $150-170 \mathrm{~m}$ higher. The Dzhankuat glacier retreated $800 \mathrm{~m}$ in length and $25 \mathrm{~m}$ in elevation (Solomina, in press). The effect on Pamir glaciers is more because of their greater size (values of retreat for the big western Pamir glaciers are up to $4000 \mathrm{~m}$ ). On the other hand, glaciers in the interior retreated much less than on the periphery, in both the Pamirs and Tien Shan.

According to estimates of glacier front positions after the end of the Little Ice Age (Solomina, in press), the height of glacier fronts in the north and east of the Tien Shan has risen $300-400 \mathrm{~m}$. In the interior Tien Shan this value is less (0$70 \mathrm{~m})$. Retreat in the Altai is also less (200-2300 m; mean value $600 \mathrm{~m}$; altitude changes $90 \mathrm{~m}$ ). In the Polar Urals and northeastern mountains of Siberia, glacier reduction is 
much less (200 m length and some meters elevation). Finally, in Kamchatka, glacier fronts are now located 50-60 m higher than their Little Ice Age moraines.

\section{Ice-core evidence}

Ice cores from glaciers provide information about crystal size, microparticle concentration, isotopic composition and temperature in boreholes. These data may indicate trends in global climate. From 1980 to 1985, ice coring was carried out at the Dzhantugan firn plateau, part of the accumulation area of Dzhankuat glacier. One of the objectives was to determine the characteristics of the firn-ice layer under conditions of infiltration-recrystallization ice formation (Golubev and others, 1988).

\section{Ice crystal diameter, $\mathrm{mm}$}

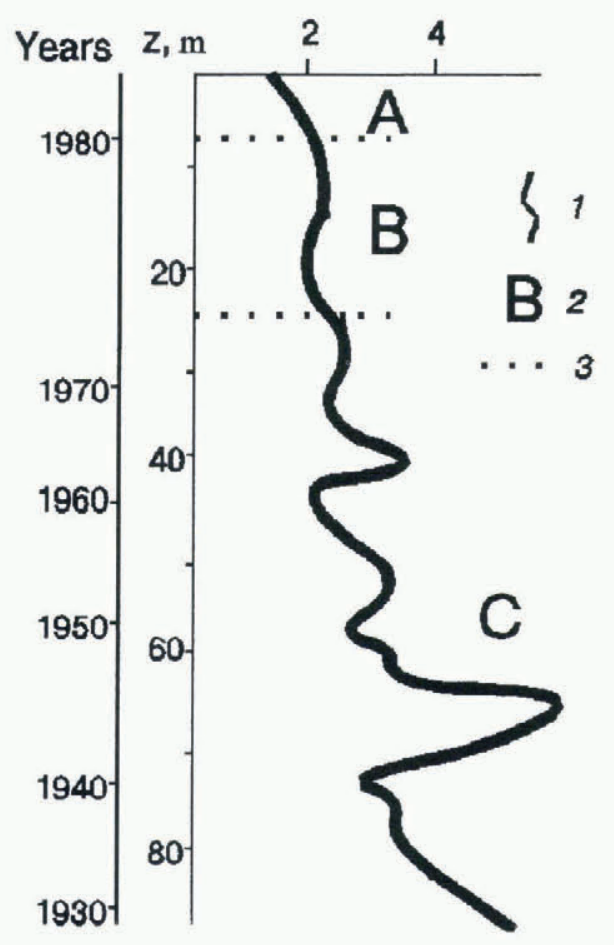

Fig. 3. Variation in grain-size with depth (1); the main zones $(A, B, C)$ of the growth of crystals in the snow-firn sequence of the Dzhantugan firn plateau (2); and the boundaries of zones (3) (after Golubev and others, 1988).

Changes in crystal size, shown in Figure 3, can be divided into three parts. The upper part presents the whole snow layer $(3-5 \mathrm{~m})$ in zone $\mathrm{A}$, where the snow structure transforms due to winter diffusion, mass transfer and infiltration, and freezing of melting water in summer. The average rate of crystal growth in this zone is $0.2-0.3 \mathrm{~mm} \mathrm{a}^{-1}$. At 5-30 m (zone B in Fig. 3) the structure of ice transforms mainly due to the influence of infiltrating meltwater. The rate of crystal growth here is $0.05-0.1 \mathrm{~mm} \mathrm{a}^{-1}$. A third region is the zone below the boundary between firn and ice (zone C) where the structure transforms due to all recrystallization processes. The rate of crystal growth here depends on the temperature of the layer slightly changing in time and depth, and the values of tensions which generally increase with depth. The rate of crystal change in this zone, within ice layers of different types, is equal on average to $2 \times 10^{-2}$ $\mathrm{mma}^{-1}$.
The rate of crystal growth within all types of ice layers is practically the same. So the considerable variations of mean crystal sizes shown in Figure 3 may only be caused by climate changes, while the ice layer lies within the zone of active ice formation (upper 5-10 $\mathrm{m}$ with an age of 2-4 years). Structural and stratigraphic features of the snowfirn layers formed within this zone remain stable under recrystallization. However, crystal size is influenced by slight oscillations caused by air bubbles and mineral particle content (Alley and others, 1986).

From a comparison of crystal-size changes with precipitation and average winter air-temperature data, from the nearest weather station at Mestia, we can conclude that in cooling and drying periods the average crystal size
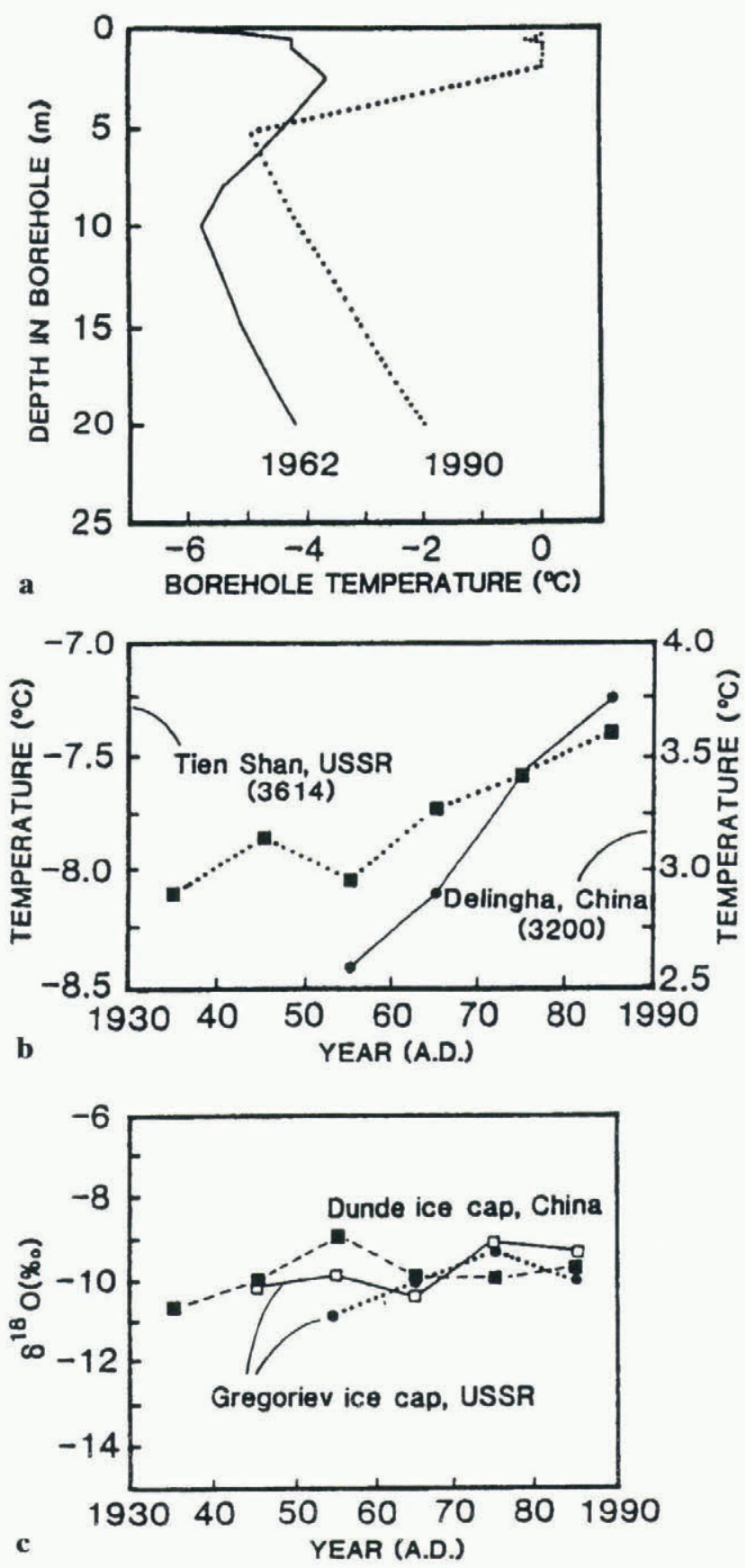

Fig. 4. (a) Borehole temperatures from Gregoriev ice cap; (b) Decadal averages of surface temperatures at the Tien Shan and Delingha meteorological stations; (c) Decadal averages of $\delta^{18} \mathrm{O}$ values in two summit cores from the Gregoriev and Dunde ice caps. 
Graham-Bell, 1994

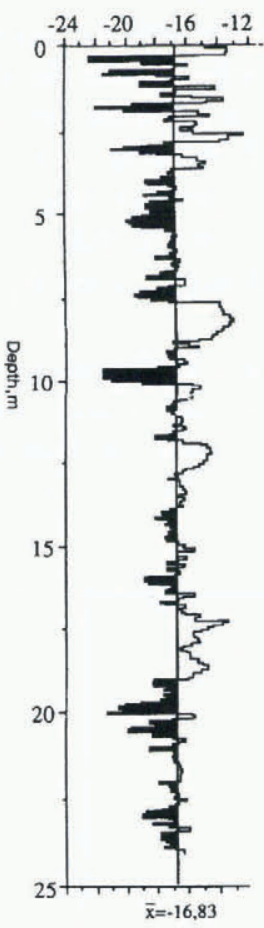

Guliya, 1992

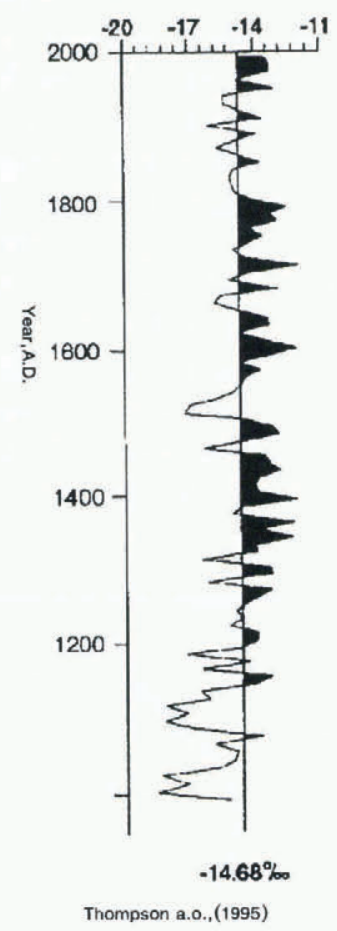

Gregoriev, 1990

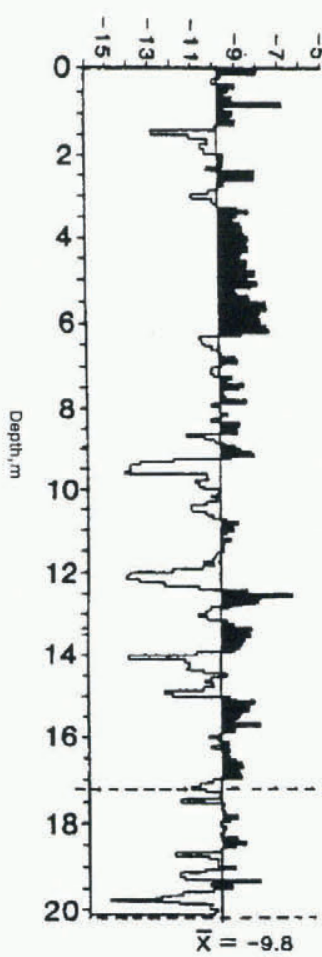

Dunde, 1987

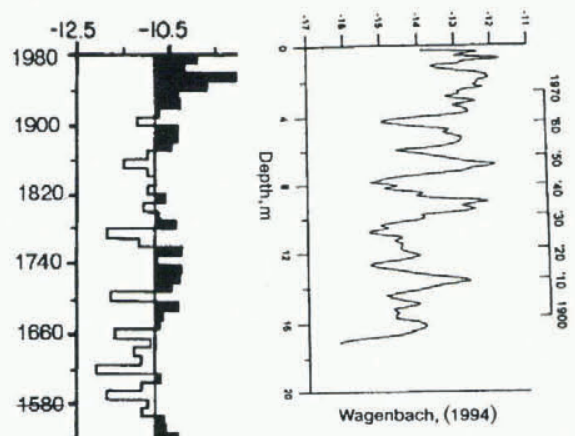

Thompson a.o., (1993)

Fig. 5. Oxygen isotope ratios from Franz Josef Land (Windy dome, Graham Bell Island), the western Kunlun (Guliya ice cap), the Tien Shan (Gregoriev ice cap), the Qilian Shan (Dunde ice cap) and the Alps (Colle Grifetti).

increases and in warming periods it decreases. The range of precipitation change at the plateau during the last 60 years is about $\pm 20 \%$, and that of the average winter air temperature is $\pm 30 \%$, from the mean annual value. If the lowering of precipitation and temperature is synchronous, the temperature gradients in the active layer of the snow-firn horizon can increase by up to $35-40 \%$, compared with periods of simultaneous warming and greater precipitation. Thus the average grain-sizes grow in periods of low winter temperatures and precipitation, compared with the warmer and higher-snowfall periods. Moreover, in these periods, ice formation occurred close to the percolation zone (Paterson, 1994), and many layers of infiltration ice were formed which also affected the growth of the average crystal size in the horizon. So, cool periods with low precipitation correspond with growth of the average crystal size, and a relative decrease in average crystal size indicates periods when ice formation occurs close to the wet-snow zone.

Repeated measurements of ice temperatures in boreholes also may show changes in the thermal regime of a glacier layer. In 1990, two boreholes were drilled in the Gregoriev ice cap, Tien Shan, to depths of 16 and $20 \mathrm{~m}$ (see Table 2). The temperature profiles (Fig. 4a) measured indicated a temperature increase of $2.2^{\circ} \mathrm{C}$ compared with the temperature profile measured in 1962. These data support evidence of a recent warming in the Tien Shan.

Further evidence of recent warming in this region comes from near-surface temperature observations at the Tien Shan meteorological station (3614 m a.s.l.; $6 \mathrm{~km}$ from the Gregoriev ice cap) and from the weather station at Delingha (3200 m a.s.l.; $100 \mathrm{~km}$ from the Dunde ice cap; see Table 2). Figure $4 \mathrm{~b}$ shows a warming of $0.5^{\circ} \mathrm{C}$ during the past 60 years at the Tien Shan station and of $1^{\circ} \mathrm{C}$ at Delingha. Figure $4 \mathrm{c}$ reflects the decadal averages of $\delta^{18} \mathrm{O}$ from both the Gregoriev and Dunde ice caps which demonstrate that over the last 40 years ${ }^{18} \mathrm{O}$ becomes isotopically enriched by approximately $1 \%$ (Thompson and others, in press).

Isotope ratios from ice cores in different parts of Eurasia show considerable enrichment in ${ }^{18} \mathrm{O}$ in the 20 th century. Oxygen isotopic ratio curves from Franz Josef Land (Windy Ice Cap, Graham Bell Island), western Kunlun Shan (Guliya ice cap), Tien Shan (Gregoriev ice cap), Qilian Shan (Dunde ice cap) and the Alps (Colle Gnifetti) (see Table 2) are shown in Figure 5. Enrichment by ${ }^{18} \mathrm{O}$ is observed at all cores. This isotopic enrichment is evidence that condensation temperatures increase considerably with the formation of solid precipitation. Such similarity in changes of isotopic composition at glaciers situated thousands of kilometers from each other suggests that this recent, continuing warming in Central Asia, the Arctic and the Alps may be a largescale feature of the current climatic regime.

\section{DISCUSSION}

The analyses of measured and reconstructed glacier mass balances, crystal-size distribution, oxygen-isotope ratios and ice temperatures measured in boreholes provide evidence of climate warming in the 20th century in Eurasia. While the glacierized area has been reduced in total, the glaciers situated in maritime climatic zones retreated much more quickly than in continental regions. However, since the 1970s, glaciers on the Pacific coast (Kozelskiy glacier) have begun to advance because of increasing accumulation.

Ice cores also contain information about global warming. In particular, ice crystals in the central Caucasus grow in cool, dry periods and decrease in warm periods. This characteristic feature is more stable than the isotopic- geochemical composition which, in warm conditions, changes considerably due to percolation of meltwater. 
The similarity of isotopic enrichment on the Gregoriev and Dunde ice caps, $1700 \mathrm{~km}$ apart, coupled with both the local meteorological observations and the $2.2^{\circ} \mathrm{C}$ increase in borehole temperatures on Gregoriev, strongly indicate recent warming in this part of Central Asia.

Considerable enrichment by ${ }^{18} \mathrm{O}$ in the upper parts of ice cores indicates recent, continuing warming in Eurasia during the past century.

\section{GONCLUSIONS}

(1) Measured and reconstructed glacier mass balances prove the considerable reduction in glacierized area from the 1880s. The rate of glacier degradation in marine climates was three times that of glaciers in continental conditions ( -480 and $-140 \mathrm{~mm} \mathrm{a}^{-1}$, respectively).

(2) The average crystal sizes reflect the climatic conditions in which the snow-firn layer was formed. In cool, dry periods crystal sizes increase and in warm, wet periods they decrease. During the last 60 years in the central Caucasus, a stable warming trend is reflected in average crystal sizes.

(3) Oxygen isotopic ratios from the Gregoriev ice cap, coupled with the $2.2^{\circ} \mathrm{C}$ increase of borehole temperatures over the last 28 years, and an increase in surface temperatures in the central Tien Shan of $0.5^{\circ} \mathrm{C}$ over the last 60 years, provide strong evidence for a recent warming in this area.

(4) Enrichment of ${ }^{18} \mathrm{O}$ provides evidence of a considerable increase of condensation temperatures over the past century.

(5) Different data on glaciers' changes, their mass balance, crystal sizes, temperatures and isotopic composition support a conclusion that climate warming is continuing during the 20th century. Moreover, the wide distribution of glaciers investigated in this study implies and confirms the global scale of the global-warming phenomenon.

\section{ACKNOWLEDGEMENTS}

The author would like to thank G. Young, J. Moore and especially an anonymous reviewer for their constructive reviews of the manuscript.

\section{REFERENCES}

Aizen, V. B. 1988. Rekonstruktiya balansa massy lednika Golubina [Golubin glacier mass balance reconstruction]. Mater. Glyatsiol. Issled. 62, 119 126.

Alley, R. B., J. H. Perepezko and C. R. Bentley. 1986. Grain growth in polar ice: I. Theory. 7. Glaciol., 32(112), 415-433.

Cherkasov, P. A. 1991. Raschet komponent vodno-lednovogo balansa kontinental'noy lednikovoy systemy na primere Dzhungarskogo Alatau [Calculation of ice-water balance components for a continental glacier system using Dzhungaria as an example]. (D.Sc. thesis, Kazakh Academy of Sciences, Alma-Ata. Institute of Geography.)

Dikikh, A. N., A. M. Sokal'skaya, M. B. Dyurgerov, I.V. Ratsek and Yang
Xinyuan. 1995. Lednikovyy stok [Glacier runoff]. In Dyurgerov, M.B., ed. Oledeneniye Tyan'-Shanya [Tien Shan glaciers]. Moscow, Vsesoyuznyy Institut Nauchnoy i Tekhnicheskoy Informatsii (VINITI), 131-168.

Dowdeswell, J. A. 1995. Glaciers in the High Arctic and recent environmental change. Philos. Trans. R. Soc. London, Ser. A, 352 (1699), 321-334.

Dyurgerov, M.B., ed. 1995. Oledeneniye Tyan'-Shanya [ Tien Shan glaciers]. Moscow, Vsesoyuznyy Institut Nauchnoy i Tekhnicheskoy Informatsii (VINITI).

Dyurgerov, M. B. and V.V. Popovnin. 1988. Reconstruction of mass balance, spatial position, and liquid discharge of Dzhankuat glacier since the second half of the 19th century. In Avsyuk, G. A., ed. Data of glaciological studies: chronicle discussions. Vol.40. Rotterdam, A. A. Balkema, 111-126.

Dyurgerov, M. B., V. N. Uvarov andT. E. Kostyashkina. 1996. Mass balance and runoff of Tuyuksu glacier and the north slope of the Zailiyskiy Alatau Range, Tien Shan. Z. Gletscherkd. Glazialgeol., 32, Part 2, 1995, 41-54.

Glazyrin, G. Ye., G. M. Kamnyanskiy and F. I. Pertsiger. 1993. Rezhim lednika Abramova [Regime of the Abramov glacier]. St Petersburg, Gidrometeoizdat.

Golubev, V. N., V. N. Mikhalenko, A. V. Serebryannikov and O. A. Gvozdik. 1988. Strukturnyye issledovaniya ledyanogo kerna Dzhantuganskogo firnovogo plato na Tsentral'nom Kavkaze [Structural studies of the ice core obtained from the Dzhantugan firn plateau in the central Caucasus]. Mater. Glyatsiol. Issled. 64, 25-33.

Koreysha, M. M. 1963. Sovremennoye oledeneniye khrebta Suntar-Khayata [Recent glaciation of the Suntar-Khayata ridge ]. Moscow, Nauka.

Krenke, A. N. 1982. Massoobmen v lednikovykh sistemakh na territorii SSSR [Mass exchange in glacier systems of the U.S.S.R.]. Leningrad, Gidrometeoizdat.

Makarevich, K.G. and 7 others. 1969. Oledeneniye Zailiyskogo Alatau [Glacierization of the Zailiyskiy Alatau]. Rezul'taty Issledovaniy po Mezhdunarodnym Geofizicheskim Proyektam. Glyatsiologiya. IX Razdel Programmy MGG 23.

Mikhalenko, V. and O. Solomina. 1996. Long-term variations of mountain glaciers in the former USSR. Part 1. Z. Gletscherkd. Glazialgeol., 32, Part 2, 1995, $159-166$.

Mikhalenko, V. N., L. G. Thompson, K. Henderson, M. E. Davis, P. N. Lin and J. Dai. 1996. Issledovaniya kerna l'da ostrova Graham-Bell na Zemle Frantsa-Iosifa [Investigations of the ice-core from Graham-Bell Island, Franz-Josef Land]. Mater. Glyatsiol. Issled. 80, 243-247.

Narozhnyy, Yu. K. 1986. Rekonstruktsiya balansa massi i zon l'doobrazovaniya lednika Maliy Aktru za 150 let [Reconstruction of the mass balance and ice formation zones of the Maliy Aktry glacier for 150 years]. Glyatsiologiya Sibiri, 3(18), 85-104.

Paterson, W. S. B. 1994. The physics of glaciers. Third edition. Oxford, etc., Elsevier.

Solomina, O. N. In press. Depressiya vysoty granitsi pitaniya gornikh lednikov byvshego SSSR v Malom Lednikovom Periode [Equilibrium line shifts in the Little Ice Age of the FSU mountain glaciers]. Mater. Glyatsiol. Issled.

Thompson, L. G. and 6 others. 1993. "Recent warming": ice core evidence from tropical ice cores with emphasis on central Asia. Global and Planetary Change, 7(1-3), 145-156.

Thompson, L. G. and 6 others. 1995. A 1000 year climatic ice-core record from the Guliya ice cap, China: its relationship to global climate variability. Ann. Glaciol., 21, 175-181.

Thompson, L. G. and 8 others. In press. Ice core records of recent climatic variability: Gregoriev and It-Tish ice caps. Mater. Glyatsiol. Issled.

Troitskiy, L. S. and 8 others. 1996. Oledeneniye Urala [Glaciation of the Urals]. Moscow, Nauka.

Ushnurtsev, S. N. 1991. Kolebaniya balansa massy lednika Sary-Tor vo Vnutrennem Tyan'-Shane i ego rekonstruktsiya za 1930-1988 gg [Mass balance fluctuations of the Sary-Tor glacier in inner Tyan'-Shan' and its reconstruction for the period 1930-1988]. Mater. Glyatsiol. Issled. 71, 70-79.

Vinogradov, V. N. and Ya. D. Murav'yev. 1992. Lednik Kozelskiy (Avachinskaya gruppa vulcanov) [Kozelskiy glacier (Avachinsky Volcano Group)]. St Petersburg, Gidrometeoizdat.

Voloshina, A. P. 1988. Some results of glacier mass balance research on the glaciers of the polar Urals. Polar Geogr. Geol., 12(3), 200-211.

Wagenbach, D. 1994. Results from the Colle Gnifetti ice-core programme. In Haeberli, W. and B. Stauffer, eds. Greenhouse gases, isotopes and trace elements in glaciers as climatic evidence of the Holocene. Zürich, Eidgenössische Technische Hochschule Versuchsanstalt für Wasserbau, Hydrologie und Glaziologie, 19-22. (Arbeitsheft 14.) 